\title{
Strategy Orientation Transformation from Market Orientation to Innovation Orientation and the Effect on Marketing Performance of Woven Industry in Wajo District, South Sulawesi Province
}

\author{
Nurhilalia ${ }^{1}$, Abd.Rahman Kadir ${ }^{2}$, Mahlia Muis ${ }^{3}$ and Jusni ${ }^{4}$ \\ ${ }^{1}$ Politeknik Negeri Ujung Pandang, Indonesia \\ ${ }^{2}$ Hasanuddin University, Indonesia \\ ${ }^{3}$ Hasanuddin University, Indonesia \\ ${ }^{4}$ Hasanuddin University, Indonesia
}

\begin{abstract}
The woven industry is an important economy actor in Wajo to bring a positive effect on trade sector. The marketing performance improvement of woven industry is done with various marketing strategies and often called the implementation of strategic orientation. This study aim is to examine the strategic orientation transformation from market orientation to innovation orientation and the effect on marketing performance of woven industry in Wajo District, South Sulawesi Province. The study uses quantitative research design with sample survey method to 99 respondents. This study was analyzed with SmartPLS3 based on variance. The conclusions are below. First, customer orientation positively effects on innovation orientation. Second, competitor orientation positively affects innovation orientation. Third, coordination between functions affect positively on innovation orientation. Fourth, customer orientation positively affects marketing performance. Fifth, competitor orientation positively affects marketing performance. Sixth, coordination between functions negatively affects marketing performance. Seventh, innovation positively affects marketing performance.
\end{abstract}

Keywords: Strategy Orientation, Market Orientation, Innovation Orientation, Marketing Performance

\section{Introduction}

Wajo District is one industrial center to produce silk in South Sulawesi Province. Silk industry is a traditional industry that has developed in community. This people woven (gedongan) is rapidly developing because of tradition of people who like to weave, and people wear silk for various kinds traditional ceremonies like marriages and harvest parties.

The Woven Industry in Wajo District is one of Leading Commodities in Industrial Sector. Data from Wajo District Statistics Agency year 2018 shows that business units to manage fabrics, sarongs, silk and non-silk are 6,093, supported by 18,150 workers spread across several sub-districts and villages. Natural matter is a series of agroindustry starting from mulberry planting, nursery and silkworm maintenance, yarn spinning, fabric woven to fabric marketing. This is home industry business that relatively easy to do, simple technology, labor intensive, quick to produce and high economic value. The woven industry becomes an important actor of economy in Wajo to bring positive effects on trade sector. The higher marketing performance makes the woven industry is done with various marketing strategies and this is often called the implementation of strategic orientation (Urata, 2000; Altindag, Zehir \& Acar (2011). It is a strategic direction of company to create the right behavior to achieve superior performance (Zhou, Yim \& Tse, 2005). Orientation Strategy has several dimensions and each researcher uses different dimensions. Grinstein (2008) used dimensions consisting of orientation market, learning orientation, entrepreneurial orientation and employee orientation. Meanwhile, Altindag et al. (2011) used customer orientation, entrepreneurial orientation, learning orientation and innovation orientation. The quality of woven industry was seen from development of production process and creating important product. This is often referred to as innovation orientation. Research on the effect of strategy orientation dimensions on marketing performance results in varied findings. This study was conducted in woven industry in Wajo District; research focus will be on 
transformation of strategy orientation from market orientation to innovation orientation and its effect on performance of woven industry in Wajo District.

Customer orientation is an organizational culture to facilitate the comprehension of targeted buyers and enables the creation of customer value continuously (Narver and Slater, 1990). Customeroriented companies generate intelligence about the current and future needs of targeted customers and disseminate new intelligence throughout the organization. Employees in customer-oriented organizations know their customers and how they should be served. They learn about their customers' needs and quick to share new information with individuals and other departments in organization to ensure that companies can keep abreast of customer needs and anticipate future needs. A critical component of customer orientation is to look at supply chain opportunities and constraints from a customer perspective (Deshpande et al., 1993; Narver and Slater, 1990). This allows companies to identify potential new customers along with opportunities to create value for customers.

Competitor orientation is an organizational culture to emphasize on comprehension of short-term strengths and weaknesses and long-term capabilities and strategies of current major competitors and potential competitors (Deshpande et al., 1993; Narver and Slater, 1990). Companies adopt competitor orientations to develop in-depth assessments of targeted competitors and potential competitors and use the knowledge generated to compensate or defeat the competition forces (Kohli and Jaworski, 1990; Olson et al., 2005). Competitor-oriented companies have competitive valuation of responsibility to senior management Employees in all organizations participate in intelligence development regarding new competitors' products and services as well as products and services offered by companies that are not considered as direct competitors. Competitor-oriented companies pay attention to use all sources to fulfil customers' needs.

Innovation plays an important role in fierce competitive business environment. As a result, researchers have provided insight on how companies innovate and how innovation spreads to other companies and individuals (Damanpour, 1991). However, many literatures focus on product innovation. Service innovation has been discussed from a conceptual perspective, but little empirical study has been done. Innovation is an idea, practice, or object that is considered new by individuals or organizations (Rogers, 2003). It can be applied to service context; a different definition for service innovation is justified to recognize the unique nature. Service innovation is the development of a new service and beneficial to a particular audience (Flint et al., 2005; Grant, 1991). The rice direct marketing is one of service innovations developed by farmers (Ady, 2015).

Narver and Slater (1990, p. 22) said that an inter-functional coordination is coordinated to use company resources to create superior value for targeted customers. An inter-functional coordination refers to specific aspects of organizational structure to facilitate communication between different organizational functions. an inter-functional is based on customer and competitor information and consists of business alignment efforts to involve more than the marketing department, to create superior value for customers. An inter-functional coordination can enhance communication and exchange between all organizational functions that pay attention to customers and competitors, and to inform trends the most up-to-date market. This helps to develop trust and independence among separate functional units, which ultimately leads to a company environment to accept a truly new product based on customer needs.

Marketing performance is part of organizational performance. Organizational performance consists of marketing performance, financial performance, and human resource performance. The company's strategy is always directed to produce marketing performance as sales volume, market share, and sales growth. Marketing performance is an effort to measure performance levels including sales turnover, number of buyers, profits and sales growth (Voss \& Voss, 2000; Ferdinand, 2006). Ferdinand (2000; p. 116) stated that marketing performance was a factor to measure the effect of a company's applied strategy. Slater and Narver (1995; p. 67) described the outcomes of implementing corporate strategy as customer satisfaction, new product success, increased sales and profitability. 


\section{Research Methodology}

This study explains the position of variables studied and relationship and the effect between one variable with another variable. According to Sugiono (2004) This is an explanatory research type to examine the relationship between variables. It uses a quantitative approach, works with numbers and analyzed by statistics tools.

The research locations to collect primary and secondary data are plantation industry in Wajo District, South Sulawesi Province.

The population is all types of woven industry in Wajo District based on data from Wajo District Statistics Agency year 2018. The business of fabrics, sarongs, silk and non-silk are 6,093 units. Samples are calculated by Slovin formula at 10\% precision, totaling 99 business units.

The samples are selected by convenience sampling technique with regard to certain conveniences as easy to find the address or willing to become respondent. It is used because some subdistricts do not have a complete names list and addresses of woven industry.

This study uses interview techniques, literature studies and questionnaires. Questionnaires are measured by five-point Likert scale.

This research aims to predict and develop theory. The right analytical tool used is SEM based on variants with partial least square (PLS). It is based on some consideration. First, this statistical method can be used to test the predictive effect for the relationship between latent variables in a model. Second, PLS can be run on small samples, does not require data with normal distribution, and can examine the research model base on weak theory (Hartono and Abdillah, 2009: 21-22). Third, PLS can combine regression methods and factor analysis in one statistical technique (Thompson, Higgins, and Howel, 1991).

The samples are 99 business actors of Woven Industry in Wajo District. Researchers classify research samples into 3 categories based on gender, woven industry and monthly sales turnover. Study results found that 65 business owners are male and 34 females. The 29 business actors engaged in industrial sector to produces 31 sarong fabrics, 31 business actors produce silk and 31 non-silks. Monthly sales turnover are 32 businesses less than IDR 5 million, 22 businesses between IDR 5 to 10 million, 26 businesses between IDR 10 to 20 million and only 19 businesses above IDR 20 million every month.

\section{Result and Discussion}

Evaluating the Goodness of Fit of Outer Model. Confirmatory Factor Analysis (CFA) has assumption of good convergent validity and significance. Convergent validity for initial stage research to develop a measurement scale should have factor value $\geq 0.50$. Bootstrapping must be done to find the significance value. If the significance value obtained from bootstrapping weight $t$-statistic test $>1.96$, it can be concluded that construct indicator is valid (Ghozali, 2015). The results of confirmatory stage 2 (end) and bootstrapping analysis are shown in table 1.

Table 1. Confirmatory and Bootstrapping Analysis

\begin{tabular}{|c|c|r|r|r|l|}
\hline Variables & Manifest & $\begin{array}{c}\text { Loading } \\
\text { Factor }\end{array}$ & Category & \multicolumn{1}{|c|}{ T-count } & Category \\
\hline \multirow{3}{*}{$\begin{array}{c}\text { Customer } \\
\text { Orientation }\end{array}$} & OPL1 & 0.602 & Valid & 5.681 & Significant \\
\cline { 2 - 6 } & OPL2 & 0.643 & Valid & 6.737 & Significant \\
\cline { 2 - 6 } & OPL3 & 0.557 & Valid & 4.520 & Significant \\
\cline { 2 - 6 } & OPL4 & 0.760 & Valid & 11.316 & Significant \\
\hline $\begin{array}{c}\text { Competitor } \\
\text { Orientation }\end{array}$ & OPS2 & 0.853 & Valid & 5.536 & Significant \\
\cline { 2 - 6 } & OPS4 & 0.588 & Valid & 2.421 & Significant \\
\hline
\end{tabular}

Source: SmartPLS3 Output (2018) 
Table 1. Cont.

\begin{tabular}{|c|c|r|r|r|l|}
\hline \multirow{2}{*}{$\begin{array}{c}\text { Variables } \\
\text { An inter- }\end{array}$} & Manifest & $\begin{array}{c}\text { Loading } \\
\text { Factor }\end{array}$ & Category & T-count & Category \\
\cline { 2 - 6 } Coordination & KAF1 & 0.672 & Valid & 9.541 & Significant \\
\cline { 2 - 6 } & KAF2 & 0.712 & Valid & 10.315 & Significant \\
\cline { 2 - 6 } & KAF3 & 0.709 & Valid & 8.857 & Significant \\
\cline { 2 - 6 } & KAF4 & 0.672 & Valid & 8.161 & Significant \\
\cline { 2 - 6 } & KAF5 & 0.546 & Valid & 5.025 & Significant \\
\hline Innovation & OIN1 & 0.675 & Valid & 7.938 & Significant \\
\cline { 2 - 6 } Orientation & OIN2 & 0.765 & Valid & 18.990 & Significant \\
\cline { 2 - 6 } & OIN4 & 0.686 & Valid & 10.364 & Significant \\
\cline { 2 - 6 } & OIN5 & 0.789 & Valid & 17.452 & Significant \\
\hline Marketing & KPS1 & 0.735 & Valid & 11.073 & Significant \\
\cline { 2 - 6 } Performance & KPS2 & 0.832 & Valid & 24.619 & Significant \\
\cline { 2 - 6 } & KPS3 & 0.780 & Valid & 13.899 & Significant \\
\cline { 2 - 6 } & KPS4 & 0.777 & Valid & 13.893 & Significant \\
\hline
\end{tabular}

Source: SmartPLS3 Output (2018)

These results indicate that items measurement of customer orientation, competitor orientation, an inter-functional coordination, innovation orientation and marketing performance variables are significant at alpha (0.05). It means customer orientation variable has 4 valid measurement statements, competitor orientation variable has 2 valid measurement statements, an inter-functional coordination variable has 5 valid measurement statements, innovation orientation variable has 4 valid measurement statements and marketing performance variable has 4 valid measurement statements. Composite Reliability. Role of thumb for explanatory or confirmatory research should have minimum value of 0.60 (Ghozali, 2015). This research will only use the composite reliability testing. The test results are shown in table 2.

Table 2. Composite Reliability

\begin{tabular}{|l|c|}
\hline \multicolumn{1}{|c|}{ Variables } & \multicolumn{1}{c|}{$\begin{array}{c}\text { Composite Reliability } \\
\text { (Original Sample) }\end{array}$} \\
\hline Customer Orientation & 0.691 \\
\hline Competitor Orientation & 0.737 \\
\hline $\begin{array}{l}\text { An inter-functional } \\
\text { Coordination }\end{array}$ & 0.797 \\
\hline Innovation Orientation & 0.820 \\
\hline Marketing Performance & 0.863 \\
\hline
\end{tabular}

Source: SmartPLS3 Output (2018)

Above test results show that outer goodness of fit model for all variables have a good level of accuracy, consistency and accuracy in measuring the constructs.

Structural Model Hypothesis Testing (Goodness of Fit Inner Model). The hypothesis will be tested by looking at Path Coefficient value. The path coefficient must be positive and significant at alpha 0.05 ; t-statistics must be greater than the 1.96 t-table. Ghozali's (2015) said that $10 \%$ significance level is t-count $>1.65$, significance level of $5 \%$, $t$-count $>1.96$ and a significance level of $1 \% \mathrm{t}$-count $>$ 2.58. The researchers do the testing with a $95 \%$ confidence level with at alpha $>0.05$. The hypothesis testing results are shown in figure 1 and table 3 . 


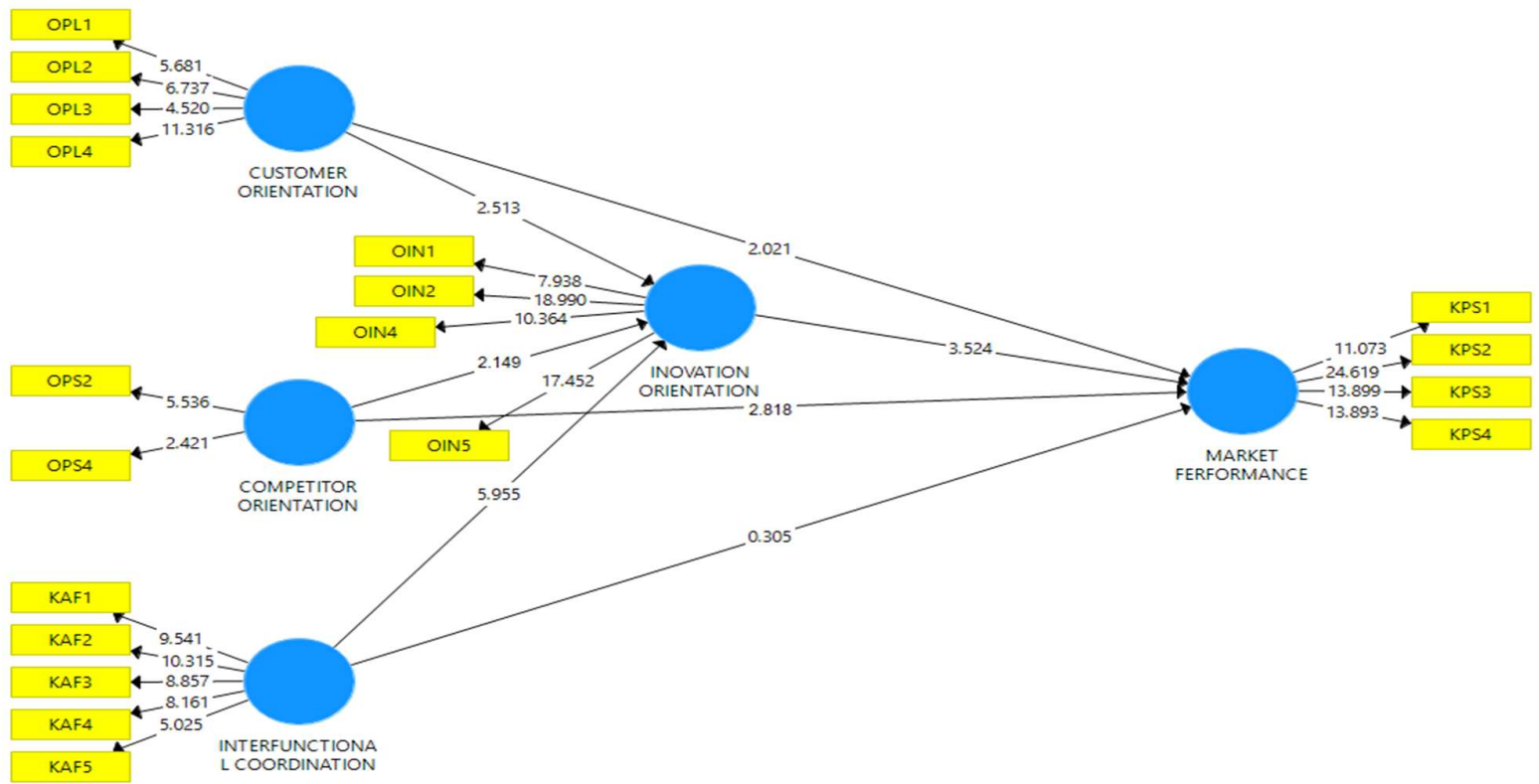

Figure 1. Hypothesis Testing Results

Table 3. Path Coefficient of Inner Model

\begin{tabular}{|c|l|c|c|c|}
\hline No & \multicolumn{1}{|c|}{ Hypotheses } & $\begin{array}{c}\text { Original } \\
\text { Sample } \\
(\mathrm{O})\end{array}$ & $\begin{array}{c}\text { T } \\
\text { Statistics } \\
(\mid \mathrm{O} / \text { STDE } \\
\mathrm{V} \mid)\end{array}$ & P Values \\
\hline 1 & $\begin{array}{l}\text { Customer Orientation } \rightarrow \text { Innovation } \\
\text { Orientation }\end{array}$ & 0.268 & 2.513 & 0.012 \\
\hline 2 & $\begin{array}{l}\text { Competitor Orientation } \rightarrow \text { Orientation } \\
\text { Innovation }\end{array}$ & 0.015 & 2.149 & 0.032 \\
\hline 3 & $\begin{array}{l}\text { Inter-functional Coordination } \rightarrow \text { Orientation } \\
\text { Innovation }\end{array}$ & 0.529 & 5.955 & 0.000 \\
\hline 4 & $\begin{array}{l}\text { Customer Orientation } \rightarrow \text { Marketing } \\
\text { Performance }\end{array}$ & 0.269 & 2.021 & 0.044 \\
\hline 5 & $\begin{array}{l}\text { Orientation Competitor } \rightarrow \text { Marketing } \\
\text { Performance }\end{array}$ & -0.035 & 0.305 & 0.761 \\
\hline 6 & $\begin{array}{l}\text { Inter-functional Coordination } \rightarrow \text { Marketing } \\
\text { Performance }\end{array}$ & 0.448 & 3.524 & 0.000 \\
\hline 7 & $\begin{array}{l}\text { Orientation Innovation } \rightarrow \text { Marketing } \\
\text { Performance }\end{array}$ & & \\
\hline
\end{tabular}

Source: SmartPLS 3 Data Results, (2018)

Hypothesis Testing 1. The first hypothesis states that customer orientation has a positive effect on innovation orientation. The test results show that customer orientation affects innovation orientation at path coefficient of 0.268 , t-statistics $2.513>\mathrm{t}$-table 1.96 and significance value (P-Values) 0.012 $<$ alpha 0.05 . It means the customer orientation has a positive and significant effect on innovation orientation of Woven Industry in Wajo District.

Hypothesis Testing 2. The second hypothesis states that competitor orientation has a positive effect on innovation orientation. The test results show that competitor orientation affects innovation orientation at path coefficient of 0.015 , t-statistic $2.149>$ t-table 1.96 and significance value (P- 
Values) $0.032<$ alpha 0.05 . It means the competitor orientation has a positive and significant effect on innovation orientation of Woven Industry in Wajo District.

Hypothesis Testing 3. The third hypothesis states that an inter-functional coordination has a positive effect on innovation orientation. The test results show that an inter-functional coordination affects innovation orientation at path coefficient of 0.529 , t-statistic of $5.955>\mathrm{t}$-table of 1.96 and significance value (P-Values) of $0.000<$ alpha 0.05 . It means an inter-functional coordination has a positive and significant effect on innovation orientation of Woven Industry in Wajo District.

Hypothesis Testing 4. The fourth hypothesis states that customer orientation has a positive effect on marketing performance. The test results show that customer orientation affects marketing performance at path coefficient of 0.269 , t-statistic of $2.021>\mathrm{t}$-table 1.96 and significance value (PValues) of $0.044<$ alpha 0.05 . It means the customer orientation has a positive and significant effect on marketing performance of Woven Industry in Wajo District.

Hypothesis Testing 5. The fifth hypothesis states that competitor orientation has a positive effect on marketing performance. The test results show that competitor orientation affects marketing performance at path coefficient of 0.083 , a t-statistic of $2.818>$ t-table of 1.96 and significance value (P-Values) $0.091>$ alpha 0.05. It means the competitor orientation has a positive and significant effect on marketing performance of Woven Industry in Wajo District.

Hypothesis Testing 6. The sixth hypothesis states that an inter-functional coordination has a positive effect on marketing performance. The test results show that an inter-functional coordination affects marketing performance at path coefficient of -0.035 , t-statistic of $0.305<\mathrm{t}$-table of 1.96 and significance value (P-Values) $0.761>$ alpha 0.05 . It means an inter-functional coordination has a negative and insignificant effect on marketing performance of Woven Industry in Wajo District.

Hypothesis Testing 7. The seventh hypothesis states that innovation orientation has a positive effect on marketing performance. The test results show that innovation orientation affects marketing performance at path coefficient of 0.448 , a t-statistic of $3.524>t$-table of 1.96 and significance value (P-Values) of $0.000<$ alpha 0.05 . It means innovation orientation has a positive and significant effect on marketing performance of Woven Industry in Wajo District.

Total Determination Coefficient. The test uses Q-square predictive relevance $\left(\mathrm{Q}^{2}\right)$ for structural models. The $\mathrm{Q}^{2}$ calculation uses $\mathrm{R}^{2}$ data from each endogenous variable. The $\mathrm{R}^{2}$ value of each endogenous variable is shown in table 4 .

Table 4. $\mathrm{R}^{2}$ Testing Results

\begin{tabular}{|l|c|}
\hline \multicolumn{1}{|c|}{ Variable Endogenous } & $\mathrm{R}^{2}$ \\
\hline Innovation Orientation & 0.625 \\
\hline Marketing Performance & 0.856 \\
\hline
\end{tabular}

The PLS model was evaluated by looking at $\mathrm{R}^{2}$ predictive relevance for the construct model. The $\mathrm{R}^{2}$ measures how well the observation value is generated by model and its parameter estimation. $\mathrm{R}^{2}$ greater than zero $(>0)$ indicates that model has a predictive relevance value, while the $\mathrm{R}^{2}$ value smaller than zero $(<0)$ indicates that the model lacks predictive relevance. $\mathrm{R}^{2}$ calculations can be calculated through the following formula:

$$
\mathrm{Q}^{2}=1-\left(1-\mathrm{R}_{1}^{2}\right)\left(1-\mathrm{R}_{2}^{2}\right)
$$

Where $\mathrm{R}_{1}^{2}, \mathrm{R}_{2}^{2}, \mathrm{R}_{\mathrm{x}}^{2}$ are $\mathrm{R}^{2}$ of endogenous variables in equation model. The implementation of $\mathrm{R}^{2}$ equation is below.

$$
\begin{aligned}
\mathrm{Q}^{2} & =1-\left(1-\mathrm{R}_{1}^{2}\right)\left(1-\mathrm{R}_{2}^{2}\right) \\
& =1-\left(1-0.625^{2}\right)\left(1-0.856^{2}\right) \\
& =1-(1-0.390)(1-0.732) \\
& =1-(0.610)(0.268) \\
& =1-0.163 \\
& =0.837
\end{aligned}
$$


The test results for goodness of fit inner model show the total $\mathrm{R}^{2}$ coefficient of 0.837 . This result describes that research model that examines the Transformation of Strategy Orientation from Market Orientation to Innovation orientation and Its Effect on Marketing Performance of Woven Industry in Wajo District, South Sulawesi Province has a level of predictive relevance. Predictive relevance value of 0.837 indicates that data variance (information content) in this study can be explained by a research model of $83.7 \%$ while the remaining $16.3 \%$ is explained by other variables outside the research model. The goodness of fit test at $83.7 \%$ shows that this research model is good enough to predict the relationship between constructs.

Effect of Customer Orientation on Innovation Orientation. Customer orientation has a positive and significant effect on innovation orientation of Woven Industry in Wajo District. The owner or manager of woven industry in Wajo District can increase technical innovation orientation by increasing the customer orientation. The technical innovation orientation level depends on customer orientation level. Various previous empirical studies have supported the study result to strengthen the results of this study.

Companies with strong customer orientation pursue competitive advantage with highest priority on creation and maintenance of customer value (Olson et al., 2005). Market intelligence is an important element of strategic orientation. The company's sustainable ability to compete is due to uniqueness of a company's intelligence (Grant, 1996; Turner and Makhija, 2006; Zander and Kogut, 1995). Customer orientation is a culture where customer needs and values are formally communicated within organization between departments and managers and informally among all employees of organization. Communication share support the development of organizational capabilities (Teece, 1998). As a result, companies must be well positioned to anticipate the needs changes and develop new products and services (Day, 1994). Specifically, researchers previously argued that service innovation can produced from company's ability to focus on customers to achieve results beyond customer expectations (Kandampully, 2002). Leaders in service industry introduce leading services that exceed customer expectations and set the pace in market (Kandampully, 2002). It is consistent with Deshpande et al. (1993).

Effect of Competitor orientation on Innovation Orientation. Competitor orientation has a positive and significant effect on innovation orientation of Woven Industry in Wajo. It is important for business actors to collectively develop and share competitive intelligence among their employees to identify competitor strengths. Woven industry needs to concern to Competitor orientation intelligence about existing competitors and potential competitors. Various previous empirical studies have supported the results of this study to strengthen this study results (Hunt and Morgan, 1996).

The competition threat may become an impetus to offer innovative services and more efficient resources usage (Dickson, 1992). It aims to balance or exceed the competitor strengths (Olson et al., 2005). Companies will search information about resources and offers from competing companies and develop innovations to get or maintain competitive advantage (Hunt and Morgan, 1996). The ability of corporate service innovation depends heavily on development of a knowledge base (Chapman et al., 2003), Han et al. (1998) stated that a competitor-centered culture contributes to intelligence related to competitors and facilitates service innovation.

Effect of an inter-functional Coordination on Innovation Orientation. An inter-functional coordination has a positive and significant effect on innovation orientation of Woven Industry in Wajo District. The innovation orientation depends heavily on an inter-functional coordination. Innovation is created through the communication process between functions of business owners, employees, customers and competitors. Previous empirical studies have supported the study results. SEM analysis shows the customer orientation is the only determinant of performance. Competitor orientation and inter-functional coordination show indirect relationships, namely through customer orientation (Tsiotsou, 2008) Functional coordination also affect positively on company performance (Johnson et al., 2009). An inter-functional coordination can enhance communication and exchange 
between all organizational functions that pay attention to customers and competitors, and to inform current market trends, Narver and Slater (1990).

Effect of Customer Orientation on Marketing Performance. Customer orientation has a positive and significant effect on marketing performance of Woven Industry in Wajo District. Customers are determinants of marketing performance. The customers number greatly affects marketing performance. Previous empirical studies have supported the results of this study. Customer orientation has a positive effect on marketing performance (Zahra \& Garvis, 2000) and Rocelis (2006) said that orientation of marketing or customer focus, innovation orientation and resources human power improves financial performance and marketing performance. Lin et al., (2008) found a positive relationship of market orientation on innovation and company performance in China. Reijonena \& Komppulab (2010) stated that dimensions of market orientation (customer orientation and competitors) are a success factor in MSMEs.

The Effect of Competitor orientation on Marketing Performance. Competitor orientation has a positive and significant effect on marketing performance of Woven Industry in Wajo District. The fierce competition between woven industry entrepreneurs not only has a negative effect but also a positive effect on business actors. Business actors are required to be more creative and innovative in managing their business to overcome the negative effect. Lin et al. (2008) found a positive relationship of market orientation on innovation and company performance in China. Reijonena \& Komppulab (2010) found that dimensions of market orientation (customer orientation and competitors) are a success factor in MSMEs. Zhi \& Jintong (2012) conducted research on MSMEs in China about differences in government, competitors and strength of corporate media and performance. The results showed the government, competitors and media forces affect the performance. Government and CSR orientation moderate the stakeholder relations of company with environmental performance. The competitor orientation affects performance.

The Effect of an inter-functional Coordination on Marketing Performance. An inter-functional coordination has a negative and insignificant effect on marketing performance of Woven industry in Wajo District. The coordination between functions directly cannot improve marketing performance. Marketing performance improvement cannot only emphasize the coordination process between functions, but also customers, competitors and business actor innovation. This study results contradict with Narver and Slater (1990, p. 22) that an inter-functional coordination to coordinate company resources can create superior value for targeted customers.

Effect of innovation orientation on marketing performance. The innovation orientation has a positive and significant effect on marketing performance of Woven Industry in Wajo District. Businesses in this digital era are required to innovate to attract consumers to buy handicrafts from woven industry. Innovation is not done only in production but also in process. Previous empirical studies have supported the results of this study. Innovation capabilities have been shown to have a positive effect on company performance (Hult et al., 2004; Panayides, 2006). One way the service innovation can benefit a company is to give new touch into existing products. This can be done by offering new services related to existing company products. The value-added nature of service innovation can enable companies to enter new markets and reach new customers (Persson, 1991). The development of entirely new services can also enable companies to reach new market segments. The example is UPS Service Part Logistics. Recognizing limited opportunities for growth in small-scale package delivery industries, UPS develop new services aimed at transporting goods quickly with short notice (Laurie et al., 2006). The new service target is companies that need to move service parts and medical products and offer new sources of growth for the company. Companies that display innovation capabilities can achieve market leadership positions (Keskin, 2006).

\section{Conclusion}

Customer orientation has a positive and significant effect on innovation orientation of Woven Industry in Wajo District. The owner or manager of woven industry in Wajo District who wants to 
increase technical innovation orientation can increase the customer orientation. The high level of technical innovation orientation depends on customer orientation level.

Competitor orientation has a positive effect on innovation orientation of Woven Industry in Wajo District. It is important for business actors to identify competitor strengths to collectively develop and share competitive intelligence among their employee about existing competitors and potential competitors.

An inter-functional coordination has a positive effect on innovation orientation of Woven Industry in Wajo District. The innovation orientation depends heavily on an inter-functional coordination, innovation is created through the process of communication between functions of business owners, employees and customers and competitors.

Customer orientation has a positive and significant effect on marketing performance of Woven Industry in Wajo District. Customers are determinants of marketing performance; customers number greatly affects marketing performance of woven industry. Customer orientation has a positive effect on marketing performance. Competitors have positives a positive affects marketing performance. In this digital era, businesspeople are required to innovate to attract consumers to buy handicraft products from woven industry. Innovation is not done in production only but also from process .

Coordination negatively affects marketing performance. An inter-functional coordination directly cannot improve marketing performance. Marketing performance improvement cannot be done only by emphasizing the coordination process between functions only but also paying attention to customers, competitors and business actors' innovation.

The innovation orientation has a positive effect on marketing performance. Businessmen in this digital era are required to innovate to attract consumers to buy handicraft products from woven industry. Innovation is not done only in production but also in process.

\section{References}

Ady, M. M. A. (2015). Findings in Interviews on Motivation of Farmers for the Improvement of Paddy Rice Quality and the Implementation of New Methods of Paddy Rice Production in the Chiba Prefecture. 人文社会科学研究 第 31 号. Retrieved from https://core.ac.uk/download/pdf/97064981.pdf

Altindag, E. Zehir, C. \& Acar, A.Z. (2010).Strategic Orientations and Their Effects on Firm Performance in Turkish Family Owned Firms, Journal Eurasian Business Review, Vol. 1. p. 18-36.

Berry, L.L., Shankar, V., Parish, J.T., Cadwallader, S. and Dotzel, T. (2006), "Creating new markets through service innovation", Sloan Management Review, Vol. 47 No. 2, pp. 56-63. Business Review, Vol. 84 No. 5, pp. 80-90.

Buono, A.F. \& Kerber, K.W. (2008). The Challenge of Organizational Change: Enhancing Organizational Change Capacity, Revue Sciences de Gestion, Vol. 65. p. 99-118.

Chapman, R.L., Soosay, C. and Kandampully, J. (2003), "Innovation in logistic services and the new business model: a conceptual framework", International Journal of Physical Distribution \& Logistics Management, Vol. 33 No. 7, pp. 630-50.

Damanpour, F. and Evan, W.M. (1984), "Organizational innovation and performance: the problem of 'organizational lag”", Administrative Science Quarterly, Vol. 29 No. 3, pp. 392-409.

Dentoni \& Domenico (2011). R\&D Projects Fostering Small Firms' Market- Sensing and CustomerLinking Capabilities: A Multivariate Statistics Approach Australian Agricultural and Resource Economics Society, Conference (55th), February 8-11, Melbourne, Australia.

Deshpande, R., Farley, J.U. and Webster, F.E. Jr (1993), "Corporate culture customer orientation, and innovativeness in Japanese firms: a quadrad analysis", Journal of Marketing, Vol. 57No. 1, pp. 23-37.

Day, G.S. (1994), “The capabilities of market-driven organizations", Journal of Marketing, Vol. 58 No. 4, pp. 37-52. Kandampully, J. (2002), "Innovation as the core competency of a service 
organisation: the role of technology, knowledge, and networks", European Journal of Innovation Management, Vol. 5 No. 1, pp. 18-26.

Dickson, P.R. (1992), "Toward a general theory of competitive rationality", Journal of Marketing, Vol. 56 No. 1, pp. 69-83.

Flint, D.J., Larsson, E., Gammelgaard, B. and Mentzer, J.T. (2005), "Logistics innovation: a customer value-oriented social process", Journal of Business Logistics, Vol. 26 No. 1,pp. 113-47.

Ferdinand, Augusty, 2000, Structural Equation Modelling dalam Penelitian Manajemen, Badan Penerbit Universitas Diponegoro, Semarang

Flint, D.J., Larsson, E., Gammelgaard, B. and Mentzer, J.T. (2005), "Logistics innovation: a customer value-oriented social process", Journal of Business Logistics, Vol. 26 No. 1, pp. 113-47

Gronroos, C. (2000), Service Management and Marketing: A Customer Relationship Management Approach, 2nd ed., Wiley, London.

Gatignon, H. And Xuereb, J. (1997), "Strategic Orientation Of The Firm And New Product Performance", Journal Of Marketing Research, Vol. 34 No. 1, Pp. 77-90.

Grant, R.M. (1996), "Towards a knowledge based theory of the firm”, Strategic Management Journal, Vol. 17, pp. 109-22.

Gravenhorst,.K.M. B., Werkman, R.A. \& Boonstra J.J. (2009). The Change Capacity of Organisations, : General Assessment and Five ConPgurations University of Amsterdam, The Netherlan.

Grawe.S.J. (2009). The Relationship Between Strategic Orientation, Service Innovation, And Performance, Emerald Group Publishing Limited.

Ghozali, Imam. (2015). Konsep Teknik dan Aplikasi Menggunakan Program SmartPLS 3.0 Edisi 2. Badan Penerbit Universitas Diponegoro. Semarang.

Grinstein, A. (2008). The Effect Of Market Orientation and Its Components on Innovation Consequences: A Meta-Analysis, Journal of Academy of Marketing Science, Vol. 36. p. 16673.

Hunt, S.D. and Morgan, R.M. (1996), "The resource-advantage theory of competition: dynamics, path dependencies, and evolutionary dimensions", Journal of Marketing, Vol. 60 No. 4, pp. 107-14.

Han, J.K., Kim, N. and Srivastava, R.K. (1998), "Market orientation and organizational performance: is innovation a missing link?", Journal of Marketing, Vol. 62 No. 4, pp. 30-45.

Hult, G.T.M., Hurley, R.F. and Knight, G.A. (2004), "Innovativeness: its antecedents and impact on business performance”, Industrial Marketing Management, Vol. 33 No. 5, pp. 429-38.

Jhonson, A.J. Dibrell, C.C. \& Eric, H. (2009). Market Orientation, Innovativeness, and Performance of Food Companies, Journal of Agribusiness, Vol. 27. p. 85-106.

Keskin, H. (2006), "Market orientation, learning orientation, and innovation capabilities in SMEs", European Journal of Innovation Management, Vol. 9 No. 4, pp. 396-417.

Kohli, A.K. and Jaworski, B.J. (1990), "Market orientation: the construct, research propositions, and managerial implications", Journal of Marketing, Vol. 54 No. 2, pp. 1-18.

King, S.B. \& Wright, M. (2007). Building Internal Change Management Capability At Constellation Energy, Organization Development Journal, vol. 25. p. 57-62.

Khan, A.M. and Manopichetwattana, V. (1989), "Innovative and noninnovative small firms: types and characteristics", Management Science, Vol. 35 No. 5, pp. 597-606.

Kirca, A, H., Jayachandran, S. and Bearden, W. O. (2005). Market Orientation: A Meta-Analityc Review and Assessment of Its Antecedents and Impact on Performance, Journal of Marketing, Vol. 69. p. 24-4.

Laurie, D.L., Doz, Y.L. and Sheer, C.P. (2006), "Creating new growth platforms”, Harvard SMEs", European Journal of Innovation Management, Vol. 9 No. 4, pp. 396-417.

Lawler III E. (2000). Designing Change Capable Organizations Ceo Publication G 00-17 (390) Center For Effective Organizations Marshall. School of Business University of Southern California. 
Lin, C.H, Peng, C.H, \& Kao, D.T. (2008). They are Innovative Tiveness Effect of Market Orientatation and Learning Orientation is a Business Performance, Journal of Manpower, Vol. 29. p. $752-772$.

Michael L. Tushman, Charles A.O Reilly, 2001, Winning Throught Innovation - A Practical Guide to Leading Organizational Change and Renewal, Harvard Business Scholl Press.

Narver, J.C. and Slater, S.F. (1990), "The effect of a market orientation on business profitability", Journal of Marketing, Vol. 54 No. 4, pp. 20-35.

Panayides, P. (2006), "Enhancing innovation capability through relationship management and implications for performance", European Journal of Innovation Management, Vol. 9 No. 4, pp. 466-83.

Persson, G. (1991), “Achieving competitiveness through logistics”, International Journal of Logistics Management, Vol. 2 No. 1, pp. 1-11.

Porter, M.E. (1985), Competitive Advantage, The Free Press, New York, NY.

Rogers, E.M. (2003), Diffusion of Innovations, 5th ed., Simon \& Schuster, New York, NY.

Rocelis, A.D. (2005). Relationship Between Strategic Orientation and Organizational Performance : An Exploratory Study of Philiphippine Companies, Philippine Management Review, Vol. 13. p. $70-80$.

Sergio, O. \& Roberto, F. (2008). Market orientation, knowledge related resources and firm performance, Journal of research business, Vol. 61. p. 623-630.

Turner, K.L. and Makhija, M.K. (2006), "The role of organizational controls in managing knowledge", The Academy of Management Review, Vol. 31 No. 1, pp. 197-217.

Teece, D.J. (1998), "Capturing value from knowledge assets: the new economy, markets for knowhow, and intangible assets", California Management Review, Vol. 40 No. 3, pp. 55-79.

Tsiotsou, R.H. (2008). Delineating The Effect Of Market Orientation On Services Performance: A Component-Wise Approach, The Service Industries Journal, Vol. 30. p. 375-403

Urata, S. (2000). Policy Recommendation for SME Promotion In The Republic of Indonesia, JICA Senior Advisor to Coordination Minister of Economy, Finance and Industry. Jakarta.

Olson, E.M., Slater, S.F. and Hult, G.T.M. (2005), "The performance implications of fit among business strategy, marketing organization structure, and strategic behavior", Journal of Marketing, Vol. 69 No. 3, pp. 49-65.

Voss, G.B., \& Voss Z.G. (2000). Strategic Orientation and Firm Performance Inan Artistic Enviroment, Journal of Marketing, Vol. 64. p. 67-83.

Zander, U. and Kogut, B. (1995), "Knowledge and the speed of the transfer and imitation of organizational capabilities: an empirical test", Organization Science, Vol. 6 No. 1, pp. 76-92.

Zahra, S.A., Ireland, R.D. \& Hutt, M.A. (2000).International Expansion by New Venture Firm: International Diversity, Mode of Market Entry, Technological Learning, and Performance, Academy of Management Journal, Vol. 43. p. 925-950.

Zhi T. \& Jintong T. (2012).Stakeholder-firm power difference, stakeholders' CSR orientation, and SMEs' environmental performance in China.Journal of Business Venturing, Vol. 27. p. 436455.

Zhou, K.Z. Yim, C.K. \& Tse, D.K. (2005). The Effects of Strategic Orientationson Technology and Market Based Breakthrough Innovations, Journal of Marketing, Vol. 69. p. 40-60. 